\title{
TERAPI DINGIN (COLD THERAPY) DALAM PENANGANAN CEDERA OLAHRAGA
}

Oleh: Novita Intan Arofah

Dosen Jurusan Pendidikan Kesehatan dan Rekreasi FIK UNY

\section{ABSTRAK}

Terapi dingin (cold therapy) merupakan modalitas fisioterapi yang banyak digunakan pada fase akut cedera olahraga. Pada fase akut, efek fisiologis terapi dingin berupa vasokontriksi arteriola dan venula, penurunan kepekaan akhiran saraf bebas dan penurunan tingkat metabolisme sel sehingga mengakibarkan penurunan kebutuhan oksigen sel. Secara klinis keseluruhan proses tadi dapat mengurangi proses pembengkakan, mengurangi nyeri, mengurangi spasme otot dan resiko kematian sel.

Terapi dingin yang banyak digunakan berupa ice massage, ice packs, cold bath/water immersion dan vapocoolant sprays. Dewasa ini terapi dingin juga banyak digabungkan dengan terapi latihan (cyrokinetics). Penggunaan terapi dingin harus dilakukan dengn prosedur yang tepat mengingat adanya beberapa resiko terapi seperti iritasi, hipothermia, frost bite. Terapi ini dikontraindikasikan pada beberapa gangguan klinis antara lain Raynaud's syndrome, cyroglobunemia, paraxoxymal hemaglobinuria, vasculitis dan gangguan syaraf sensoris seperti pada diabetes mellitus.

Kata kunci : terapi dingin (cold therapy), cedera olahraga

Cedera olahraga secara umum dibedakan menjadi cedera traumatis dan cedera berkelanjutan (overuse injuries). Cedera traumatis terjadi akibat benturan sedangkan overuse injury terjadi akibat

Terapi Dingin (Cold Therapy) Dalam Penanganan Cedera... (Novita Intan Arovah) 
beban kerja fisiologis yang berlebihan. Bentuk cedera dapat berupa memar, strain, sprain sampai dengan fraktur tulang. Respon tubuh terhadap kerusakan jaringan ini berupa reaksi peradangan (inflamasi) y’ang dipicu oleh mediator inflamasi yang dihasilkan oleh sel yang rusak maupun mati. Karakteristik peradangan berupa nyeri (dolor), pembengkakan (tumor), kemerahan (rubor), peningkatan suhu (kalor) serta penurunan fungsi (function leissa). Pada keadaan ini terjadi kerúsakan pembuluh darah yang menimbulkan perdarahan pada jaringan. Pada stadium lanjut terjadi proses penjendalan yang difasilitasi oleh trombosit, faktor penjendalan darah dan fibroblast yang membentuk jaringan parut. Apabila terjadi kegagalan maupun keterlambatan proses penyembuhan, respon tubuh memasuki fase kronis. Pada fase ini sudah tidak dijumpai tanda peradangan yang dominan kecuali penurunan fungsi dan rasa nyeri. Tahap peradangan merupakan bagian dari proses penyembuhan, walaupun demikian respon peradangan yang berlebihan dapat memperlambat proses penyembuhan akibat dari limbah metabolisme yang berlebihan sehingga pada fase akut dilakukan usaha untuk menekan respon peradangan.

Dewasa ini terapi dingin banyak digunakan pada fase akut cedera olahraga. Berbagai bentuk terapi seperti masase es, ice pack, cold bath, vapocoolant spray dan cyrokinetics digunakan untuk mengatasi peradangan dan mengurangi waktu yang diperlukan untuk pemulihan cedera lewat berbagai mekanisme fisiologis

MEDIKORA Vol. V, No 1, April 2009: 102-117 
(Hurme et al., 1993:46). Perubahan suhu jaringan bervariasi tergantung bentuk terapi, waktu pemaparan, suhu awal dan lokasi anatomis (Bleakley et al., 2004:251). Efek fisiologis terapi dingin disebabkan oleh penurunan suhu jaringan yang mencetuskan perubahan hemodinàmis lokal dan sistemik serta adanya respon neuromuscular. Terapi dingin secara klinis dapat meningkatkan ambang nyeri, mencegah pembengkakan dan menurunkan performa motorik lokal (Hocutt, 1982:316). Walaupun demikian aplikasi dingin yang berkepanjangan harus dihindari untuk mencegah terjadinya efek samping antara lain iritasi, hipothermia dan frost bite (Swenson et al., 1996:193). Penggunaan terapi dingin harus dilakukan pada indikasi yang tepat serta dihindari pada keadaan yang merupakan kontra indikasi. Pengertian, efek fisiologis, bentuk penggunaan, indikasi, kontraindikasi serta resiko terapi dingin akan dibahas lebih lanjut pada artikel ini.

\section{PENGERTIAN DAN EFEK FISIOLOGIS TERAPI DINGIN (COLD THERAPY)}

Cold therapy adalah pemanfaatan dingin untuk mengobati nyeri dan mengurangi gejala peradangan lainnya. Istilah cryotherapy digunakan untuk penggunaan terapi dingin yang sangat ekstrim, biasanya mengunakan cairan nitrogen yang digunakan sebagai anesthetic-analgesia (Swenson et al., 1996:193). Pada terapi dingin, digunakan modalitas terapi yang dapat menyerap suhu jaringan sehingga terjadi penurunan suhu jaringan melewati mekanisme konduksi. Efek pendinginan yang terjadi

Terapi Dingin (Cold Therapy) Dalam Penanganan Cedera... (Novita Intan Arovah) 
tergantung jenis aplikasi terapi dingin, lama terapi dan konduktivitas. Pada dasarnya agar terapi dapat efektif, lokal cedera harus dapat diturunkan suhunya dalam jangka waktu yang mencukupi (Bleakley et al., 2004:251).

Inti dari terapi dingin adalah menyerap kalori area lokal cedera sehingga terjadi penurunan suhu. Berkait dengan hal ini, jenis terapi dengan terapi es basah lebih efektif menurunkan suhu dibandingkan es dalam kemasan mengingat pada kondisi ini lebih banyak kalori tubuh yang dipergunakan untuk mencairkan es (Ernst et al., 1994:56). Semakin lama waktu terapi, penetrasi dingin semakin dalam. Pada umumnya terapi dingin pada suhu $3,5{ }^{\circ} \mathrm{C}$ selama 10 menit dapat mempengaruhi suhu sampai dengan $4 \mathrm{~cm}$ dibawah kulit (Ernst et al., 1994:56). Jaringan otot dengan kandungan air yang tinggi merupakan konduktor yang baik sedangkan jaringan lemak merupakan isolator suhu sehingga menghambat penetrasi dingin (Ernst et al., 1994:56).

Tabel 1. Efek Fisiologis dan Terapetis Terapi Dingin

\begin{tabular}{|c|c|c|}
\hline $\begin{array}{l}\text { Efek Fisiologis } \\
\text { Sistemik }\end{array}$ & $\begin{array}{l}\text { Efek Fisiologis } \\
\text { Lokal }\end{array}$ & Efek Terapetis \\
\hline $\begin{array}{l}>\text { Vasokontriksi } \\
>\text { Piloereksi } \\
>\text { Menggigil }\end{array}$ & $\begin{array}{l}> \\
>\end{array} \begin{array}{l}\text { Vasokontriksi } \\
\text { lokal } \\
\text { Desensitisasi } \\
\text { akhiran saraf } \\
\text { bebas } \\
>\begin{array}{l}\text { Penururunan } \\
\text { refill kapiler }\end{array} \\
>\begin{array}{l}\text { Penurunan } \\
\text { metabolism sel }\end{array}\end{array}$ & 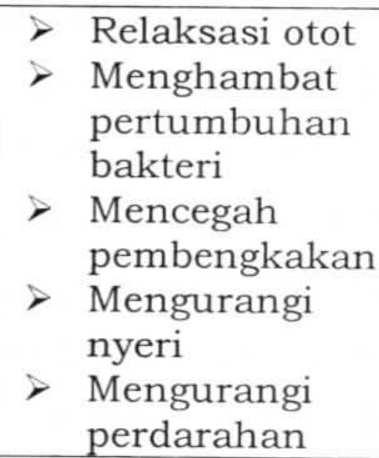 \\
\hline
\end{tabular}

MEDIKORA Vol. V, No 1, April 2009: 102-117 
((Ernst et al., 1994:56)

Terapi dingin dapat dipakai dalam beberapa moda, seperti penggunaan es dan cold baths. Aplikasi dingin dapat mengurangi suhu daerah yang sakit, membatasi aliran darah dan mencegah cairan masuk ke jaringan di sekitar luka. Hal ini akan mengurangi nyeri dan pembengkakan. Aplikasi dingin dapat mengurangi sensitivitas dari akhiran syaraf yang berakibat terjadinya peningkatan ambang batas rasa nyeri. Aplikasi dingin juga akan mengurangi kerusakan jaringan dengan jalan mengurangi metabolisme lokal sehingga kebutuhan oksigen jaringan menurun. Respon neurohormonal terhadap terapi dingin adalah sebagai berikut :

$>$ Pelepasan endorphin

$>$ Penurunan transmisi saraf sensoris

- Penurunan aktivitas badan sel saraf

> Penurunan iritan yang merupakan limbah metabolisme sel

$>$ Peningkatan ambang nyeri

Secara fisiologis, pada 15 menit pertama setelah pemberian aplikasi dingin (suhu $10^{\circ} \mathrm{C}$ ) terjadi vasokontriksi arteriola dan venula secara lokal. Vasokontriksi ini disebabkan oleh aksi reflek dari otot polos yang timbul akibat stimulasi sistem saraf otonom dan pelepasan epinehrin dan norepinephrin. Walaupun demikian apabila dingin tersebut terus diberikan selama 15 sampai dengan 30 menit akan timbul fase vasodilatasi yang terjadi intermiten

$\overline{\text { Terapi Dingin (Cold Therapy) Dalam Penanganan Cedera... (Novita Intan Arovah) }}$ 
selama 4 sampai 6 menit (Hurme et al., 1993:46). Periode ini dikenal sebagai respon hunting. Respon hunting terjadi untuk mencegah terjadinya kerusakan jaringan akibat dari jaringan mengalami anoxia jaringan (Ernst et al., 1994:56).

Selain menimbulkan vasokontriksi, sensasi dingin juga menurunkan eksitabilitas akhiran saraf bebas sehingga menurunkan kepekaan terhadap rangsang nyeri. Aplikasi dingin juga dapat mengurangi tingkat metabolisme sel sehingga limbah metabolisme menjadi berkurang. Penurunan limbah metabolisme pada akhirnya dapat menurunkan spasme otot.

Tabel 2. Respon Kulit Pada Aplikasi Dingin

\begin{tabular}{|l|l|l|}
\hline Tahap & $\begin{array}{l}\text { Waktu Pemberian Aplikasi } \\
\text { Dingin }\end{array}$ & Respon \\
\hline 1 & $0-3$ menit & Sensasi dingin \\
\hline 2 & $2-7$ menit & Rasa terbakar, Nyeri \\
\hline 3 & $5-12$ menit & Anestesi relatif kulit \\
\hline
\end{tabular}

(Ernst et al., 1994:56)

Pada umumnya dingin lebih mudah menembus jaringan dibandingkan dengan panas. Ketika otot sudah mengalami penurunan suhu akibat aplikasi dingin, efek dingin dapat bertahan lebih lama dibandingkan dengan panas karena adanya lemak subcutan yang bertindak sebagai insulator. Di sisi lain lemak sub kutan merupakan barier utama energi dingin untuk menembus otot. Pada individu dengan tebal lemak sub kutan setebal $2 \mathrm{~cm}$,

MEDIKORA Vol. V, No 1, April 2009: 102-117 
energi dingin dapat menembus jaringan otot dalam waktu 10 menit (Ernst et al., 1994:56).

Tabel 3. Efek Fisiologis Tubuh pada Terapi Dingin

\begin{tabular}{|l|l|}
\hline Variabèl & Efek \\
\hline Spasme otot & Menurun \\
\hline Persepsi Nyeri & Menurun \\
\hline Aliran darah & Menurun sampai 10 menit pertama \\
\hline $\begin{array}{l}\text { Kecepatan } \\
\text { metabolisme }\end{array}$ & Menurun \\
\hline Elastisitas kolagen & Menurun \\
\hline Kekakuan sendi & Meningkat \\
\hline Permeabilitas kapiler & Meningkat \\
\hline Pembengkakan & $\begin{array}{l}\text { Dapat mengurangi pembengkakan lanjut } \\
\text { tapi relatif tidak menghentikan } \\
\text { pembengkakan yang sudah terjadi }\end{array}$ \\
\hline
\end{tabular}

(Konrath et al., 1996:629)

Untuk cedera akut, terapi dingin sering digunakan bersamasama dengan teknik pertolongan pertama pada cedera yang disebut RICE (rest, ice, compression and elevation). Teknik ini meliputi :

Mengistirahatkan bagian tubuh yang cedera.

Memberikan es selama dua hari setelah cedera untuk mencegah pembengkakan luka.

> Mempergunakan kompresi elastis selama dua hari untuk mencegah pembengkakan. 
Berusaha agar bagian yang cedera ada di atas letak jantung untuk mengurangi kemungkinan terjadinya pembengkakan.

Dalam perawatan nyeri yang disebabkan karena cedera, terapi dingin dilakukan sampai pembengkakan berkurang. Terapi dingin biasanya digunakan pada 24 sampai 48 jam setelah terjadinya cedera dan dipakai untuk mengurangi sakit dan pembengkakan. Panas selanjutnya digunakan dalam fase rehabilitasi fase kronis (Hubbard et al., 2004:278).

\section{INDIKASI TERAPI DINGIN (COLD THERAPY)}

Menurut Konrath et.al (1996:630) beberapa kondisi yang dapat ditangani dengan cold therapy antara lain :

1. Cedera (sprain, strain dan kontusi)

2. Sakit kepala (migrain, tension headache dan cluster headache).

3. Gangguan temporomandibular (TMJ disorder).

4. Testicular dan scrotal pain.

5. Nyeri post operasi..

6. Fase akut arthritis (peradangan pada sendi).

7. Tendinitis dan bursitis.

8. Carpal tunnel syndrome.

9. Nyeri lutut.

10. Nyeri sendi.

11. Nyeri perut. .

MEDIKORA Vol. V, No 1, April 2009: 102-117 


\section{KONTRA INDIKASI TERAPI DINGIN (COLD THERAPY)}

Cold therapy sangat mudah digunakan, cepat, efisien dan ekonomis. Akan tetapi terdapat beberapa kondisi yang dapat dipicu oleh cold therapy. Individu dengan riwayat gangguan tertentu memerlukan pengawasan yang ketat pada terapi dingin. Beberapa kondisi tersebut diantaranya adalah :

1. Raynaud's syndrom yang merupakan kondisi dimana terdapat hambatan pada arteri terkecil yang menyalurkan darah ke jari tangan dan kaki ketika terjadinya dingin atau emosi. Pada keadaan ini timbul sianosis yanga pabila berlanjut dapat mengakibatkan kerusakan anggota tubuh perifer (Swenson et al., 1996:193).

2. Vasculitis (peradangan pembuluh darah) (Swenson et al., 1996: 193).

3. Gangguan sensasi saraf misal neuropathy akibat diabetes mellitus maupun leprosy. (Ernst et al., 1994:56)

4. Cryoglobulinemia yang merupakan kondisi berkurangnya protein di dalam darah yang menyebabkan darah akan berubah menjadi gel bila kena dingin (Hocutt, 1982:316).

5. Paroxysmal cold hemoglobinuria yang merupakan suatu kejadian pembentukan antibodi yang merusak sel darah merah bila tubuh dikenai dingin. (Hocutt, 1982:316).

$\overline{\text { Terapi Dingin (Cold Therapy) Dalam Penanganan Cedera... (Novita Intan Arovah) }}$ 


\section{RESIKO TERAPI DINGIN (COLD THERAPY)}

Bila terapi dingin dilakukan dalam jangka waktu yang lama, hal ini akan menyebabkan :

1. Hypothermia yang merupakan suatu kondisi medis dimana suhu tubuh menurun secara cepat dibawah suhu normal, sehinga merusak metabolisme tubuh (Ernst et al., 1994:56).

2. Excema kulit dapat terjadi pada pendinginan kulit selama 1 jam pada suhu $0^{\circ}$ sd $-9^{\circ} \mathrm{C}$. Excema ini dapat bertahan sampai dengan 24 jam (Bleakley et al., 2004:251).

3. Frostbite yang merupakan kondisi medis dimana kulit dan jaringan tubuh rusak karena suhu dingin. Frostbite (rusakya anggota tubuh perifer) dapat terjadi pada suhu $-3^{\circ}$ sd $-4^{\circ} \mathrm{C}$ (Bleakley et al., 2004:251).

\section{JENIS APLIKASI TERAPI DINGIN (COLD THERAPY)}

Terapi dingin dapat digunakan dalam beberapa cara. Pada cedera olahraga beberapa teknik yang sering dipergunakan adalah es dan masase es, imersi air dan atau es, ice packs dan vacpocoolant sprays, termasuk :

\section{Es dan Masase Es}

Peralatan: Pada terapi ini es dapat dikemas dengan berbagai cara. Salah satunya adalah dengan membekukan es pada styrofoam. Pada penggunaannya ujung stryofoam dapat digunakan sebagai pegangan pada saat dilakukan terapi. Es 
dalam pemakaiannya sebaiknya tidak kontak langsung dengan kulit dan digunakan dengan perlindungan seperti dengan handuk. Handuk juga diperlukan untuk mennyerap es yang mencàir.

Indikasi : Indikasi terapi es adalah pada bagian bagian otot lokal seperti tendon, bursae maupun bagian bagian myofacial trigger point.

Penggunaan: Es dapat digunakan langsung untuk memijat atau untuk memati-rasakan jaringan sebelum terapi pijat. Masase es dapat memberikan dingin yang lebih efisien daripada cold packs atau metode lain yang menggunakan terapi dingin. Terapi biasanya diberikan selama 10 sampai 20 menit (Swenson et al., 1996:193).

\section{Ice packs.}

Peralatan: Pada prinsipnya ice packs merupakan kemasan yang dapat menyimpan es dan membuat es tersebut dapat terjaga dalam waktu relatif lama di luar freezer daripada kemasan plastik. Alat ini tersedia di apotek dan toko obat. Sebagian besar ice packs mengandung bahan kimia yang dapat mempertahankan suhu dingin dalam jangka waktu lama. Bahan kimia seperti isopropyl alkohol dapat ditambahkan denagn rasio 2 :1 terhadap air untuk mencegah terjadinya pembekuan sehingga ketika dipergunakan, ice packs dapat mengisi kontur tubuh. Terdapat dua jenis ice packs yaitu yang berbahan gel hypoallergenic dan yang berisi cairan atau kristal.

Terapi Dingin (Cold Therapy) Dalam Penanganan Cedera... (Novita Intan Arovah) 
Penggunaan : Pada umumnya ice packs dapat dipergunakan selama 15 sampai 20 menit. Pada kemasan ice packs yang berupa plastik, diperlukan handuk untuk mengeringkan air kondensási.

Indikasi : Sama dengan ice massage.

Perhatian khusus : pengguna ice packs lebih praktis akan tetapi apabila terjadi kebocoran kemasan dapat menimbulkan bahaya iritasi kulit akibat bahan kimia yang dikandungnya (Swenson et al., 1996:193).

\section{Vapocoolant spray.}

Peralatan: Vapocoolant spray merupakan semprotan yang biasanya berisi fluoromethane atau ethyl chloride.

Indikasi : Vacoopolant spray sering digunakan untuk mengurangi nyeri akibat spasme otot serta meningkatkan range of motion.

Penggunaan : Untuk meningkatkan range of motion, terdapat beberapa prosedur pemakaian yakni :

a. vapocoolant membentuk sudut $30^{\circ}$ dengan kulit dengan jarak 30 sampai $50 \mathrm{~cm}$ dari kulit

b. penyemprotan dilakukan dari arah proksimal ke distal otot

c. kecepatan penyemprotan sékitar $10 \mathrm{~cm}$ per detik dan dapat diulang sampai dengan 2-3 kali.

Perhatian khusus : penggunaan vapocoolant harus dilakuakn sesuai prosedur untuk menghindari frozen bite (Swenson et al., 1996: 193).

MEDIKORA Vol. V, No 1, April 2009: 102-117 


\section{Cold baths / Water immersion}

Peralatan: Cold baths merupakan terapi mandi di dalam air dingin dalm jangka waktu maksimal 20 menit. Peralatan yang dipergunakan tergantung bagian tubuh yang akan direndam. Pada perendaman seluruh tubuh diperlukan tanki whirpool. Pada terapi ini aitr dan es dicampur untuk mendpatkan suhu $10^{\circ}$ sampai dengan $15^{\circ} \mathrm{C}$.

Indikasi : Terapi ini biasanya dilakukan untuk pemulihan paska latihan maupun kompetisi

Penggunaan : Penderita berendam di dalam air yang sudah didinginkan. Proses ini berlangsung sekitar 10 sampai dengan 15 menit. Ketika nyeri berkurang, terapi dihentikan dan dilanjutkan terapi lain seperti massage atau stretching. Pada saat nyeri kembali dirasakan, dapat dilakukan perendaman kembali. Dalam tiap sesi terapi, perendaman kembali dapat dilakukan sampai tiga kali ulangan.

Perhatian khusus : Terapi dingin berpotensi untuk meningkatkan penjendalan kolagen, konsekuensinya aktivitas fisik harus dilakukan secara bertahap paska terapi dingin (Swenson et al., 1996:193).

\section{CYROKINETICS}

Cyrokinetics merupakan teknik yang mengkombinasikan terapi dingin dengan latihan fișik (Hubbard et al., 2004:278). Tujuan dari terapi dingin adalah untuk mengurangi nyeri, 
sedangkan latihan fisik digunakan untuk meningkatkan jangkauan gerak. Teknik ini diawali dengan penggunaan terapi dingin sampai dirasakan pengurangan nyeri. Pada umumnya sensasi ini dirasakan dðlam 12 sampai dengan 20 menit. Setelah dilakukan terapi dingin dilakukan latihan fisik untuk meningkatkan jangkauan gerak (Hubbard et al., 2004:278). Hilangnya rasa nyeri biasanya berlangsung selama 3 sampai 5 menit. Latihan dihentikan apabila timbul rasa nyeri. Setelah rasa nyeri timbul, terapi dingin dapat diulang lagi sampai dengan tiga kali.

\section{Ringkasan Prosedur Cyrokinetics}

1. Rendam bagian yang nyeri dalam air dingin (12-20 menit)

2. Latihan dilakukan selama rasa sakit tidak menyerang (3-5 menit)

3. Pada saat nyeri muncul kembali dapat dilakukan perendaman kembali dengan air dingin (3-5 menit)

4. Siklus latihan perendaman dapat dilakukan sampai dengan 3 kali ulangan

5. Prinsip Latihan

a. Latihan bersifat aktif tanpa bantuan

b. Latihan harus bebas rasa nyeri

c. Latihan dimulai dengan latihan ringan yang dinaikan intensitas dan tingkat kesulitannya secara bertahap. (Hubbard et al., 2004:278)

MEDIKORA Vol. V, No 1, April 2009: 102-117 


\section{KESIMPULAN}

Terapi dingin (cold therapy) adalah penggunaan dingin untuk menanggulangi nyeri atau kondisi lainnya. Dewasa ini terapi dingin sering digunakan untuk mengatasi cedera olahraga. Efek fisiologis yang ditimbulkan terapi dingin berupa vasokontriksi arteriola dan venula, penurunan kepekaan akhiran saraf bebas dan penurunan tingkat metabolisme sel sehingga mengakibatkan penurunan kebutuhan oksigen sel. Secara klinis keseluruhan proses tadi dapat mengurangi proses pembengkakan, mengurangi nyeri, mengurangi spasme otot dan resiko kematian sel. Terapi dingin yang banyak digunakan berupa ice massage, ice packs, cold bath/water immersion dan vapocoolant sprays. Dewasa ini terapi dingin juga banyak digabungkan dengan terapi latihan (cyrokinetics). Penggunaan terapi dingin harus dilakukan dengan prosedur yang tepat mengingat adanya beberapa resiko terapi seperti iritasi, hipothermia, frost bite. Terapi ini dikontraindikasikan pada beberapa gangguan klinis antara lain Raynaud's syndrome, cyroglobunemia, paraxoxymal hemaglobinuria, vasculitis dan gangguan syaraf sensoris seperti pada diabetes mellitus.

\section{Daftar Pustaka}

Bleakley, C., S. McDonough and D. MacAuley (2004). "The use of ice in the treatment of acute soft-tissue injury." The American journal of sports medicine 32(1): 251.

\footnotetext{
Terapi Dingin (Cold Therapy) Dalam Penanganan Cedera... (Novita Intan Arovah)
} 
Ernst, E. and V. Fialka (1994). "Ice freezes pain? A review of the clinical effectiveness of analgesic cold therapy." Journal of pain and symptom management $\mathbf{9}(1)$ : 56 .

Hocutt, J. E! (1982). "Cryotherapy in ankle sprains." The American journal of sports medicine 10(5): 316 .

Hubbard, T. J. and C. R. Denegar (2004). "Does cryotherapy improve outcomes with soft tissue injury?" Journal of athletic training 39(3): 278.

Hurme, T., J. Rantanen and H. Kaliomo (1993). "Effects of early cryotherapy in experimental skeletal muscle injury." Scandinavian journal of medicine \& science in sports $3(1)$ : 46.

Konrath, G. A., T. Lock, H. T. Goitz and J. Scheidler (1996). "The use of cold therapy after anterior cruciate ligament reconstruction: a prospective, randomized study and literature review." The American journal of sports medicine 24(5): 629.

Swenson, C., L. Swärd and J. Karlsson (1996). "Cryotherapy in sports medicine." Scandinavian journal of medicine \& science in sports 6(4): 193.

MEDIKORA Vol. V, No 1, April 2009: 102-117 